\section{Growth continues in adversity}

EXCEPT for a few blackspots (Britain, for example), research budgets were dealt with generously last year, despite economic uncertainty. In the United States, a more than usually chaotic budget process produced unexpected largesse. What the future holds is another matter.

Even as late as the summer, most portents in the United States were gloomy. With the congressional appropriations process more bedraggled than ever, and with the prospect that deficit negotiations and partisan infighting would literally paralyse the government by denying it funds, a Congress philosophically supportive of science took to warning of austerity across the board.

By late October, science - especially biomedical science - had magically defied the odds. Support for the National Institutes of Health was increased by more than 10 per cent, or $\$ 850$ million, compared with 1990 (which, fiscally, ended in September). The National Aeronautics and Space Administration also did well, with an increase of $\$ 1,646$ million, although Congress cut funds for the space station and eliminated all support for a mission to Mars.

But elsewhere, initial optimism turned to disappointment. The National Science Foundation's 13 per cent increase evaporated when, at the last minute, the agency was forced to absorb an unexpected $\$ 40$ million in the costs of operating its Antarctic research programme. Physics and materials sciences will suffer as a consequence, with less support, in real dollars, than last year. Worse, the planned five-year doubling of the agency's budget had once again been put off.

Another casualty was the Department of Energy's magnetic fusion programme. The Congress cut $\$ 50$ million from the President's request, reducing the programme to 15 per cent below the level of 1990 . The result will be no growth and probably layoffs - in a field once again attractive as a potential long-term palliative to global warming.

Congressional reasoning seems to have been that, if fusion energy is 40 years off, this year's cuts will at worst extend the delay to 41 years. But other fields would suffer more in the short term and thus warrant more immediate priority, Yet the impending loss of fusion researchers is likely to have lasting repercussions.

In Japan, similarly, a perennially straitened government has found the means for a significant increase of direct support for university research. It will be interesting, and important, to learn in due course whether this will be offset, and to what degree, by a reduction of industrial research activity, more than threequarters of Japan's total.
The research budget has also risen in France by about 8 per cent, substantially more than nominal inflation, which hovers around 3 per cent. But researchers complain that prices of everyday items, such as reagents, have far outstripped inflation. Money at the bench, they say, is even slightly less than ten years ago in real terms.

Although the Mitterrand government has halted and even reversed the previous downward trend in research jobs, anxiety persists that new recruitment is insufficient. Thus the FF10,000 million $(\$ 2,000$ million) Centre National de la Recherche Scientifique (CNRS) is worried that young talent is being recruited on too meagre a scale to offset massive retirements later this decade.

Last year, the European Communities (EC) also put together their third fiveyear framework research and development programme, marked by an expansion into basic research. More than 500 million ECU (about $£ 350$ million) has been set aside for the 'human capital and mobility' programme, intended to replace the much smaller current programme of support for basic research, which is due to end in 1992.

But a row broke out when it emerged that European Commission VicePresident Filippo Pandolfi wanted to spend about 80 per cent of the new money on postdoctoral exchanges between EC member states. There was no demand for such a large postdoctoral programme, the member states argued, and more money is now expected to be spent on large laboratories and travel grants to encourage links between established research groups.

In Germany, reunification has created special problems (see page 3), but only Britain seems to be a glaring exception to the rule that industrialized governments seek to spend more, not less, on research.

After two years in which the Department of Education and Science's spending on the research councils increased, the budget for 1991-92, announced in November, threw British science into crisis. Although Education and Science

\section{TOWARDS A NEW YEAR}

THIS compilation by regular contributors is intended to remind readers of last year's events and to look forward to the year ahead. Its authors include Peter Aldhous (London), Christopher Anderson (Washington), Steven Dickman (Munich), Diane Gershon (Washington), David Lindley (Washington), Elizabeth Schaefer (San Francisco), Seth Shulman (Boston) and David Swinbanks (Tokyo). $\square$
Secretary Kenneth Clarke described the budget as a "real terms level settlement", outsiders say that inflation will leave the research councils with less to spend next year than this.

The pinch was felt first by the Medical Research Council (MRC), which fared worst in the allocation of the 1990-91 science budget last January. Facing with overspending of $£ 3.5$ million before April 1991, MRC froze new appointments and equipment purchases and postponed more than 80 new research grants.

Now, with the announcement of the 1991-92 budget, the Science and Engineering Research Council (SERC) has calculated that it must save $£ 40$ million in the coming year and has launched a similar cost-cutting package. Several projects will have to be delayed, including the plan (agreed in principle) to collaborate with the United States and Canada on a scheme to build an 8-metre optical telescope.

The other research councils, more used to financial attrition, have not yet been forced to renege on the consideration of research grant proposals. The Natural Environment Research Council may be protected to some extent by the current popularity of environmental issues and research.

Changes of personnel may matter. The appointment of a biologist, Sir Mark Richmond, as chairman of SERC, has prompted a review of SERC spending on 'big science' and large international collaborations; this is bound to be an important issue in 1991.

Beleaguered British scientists also hope that the replacement of former chemist Margaret Thatcher as Prime Minister by the non-scientist John Major will improve the climate. Later this month, the Conservative MP Sir Ian Lloyd leads a delegation of eminent British scientists, including two members of the well-respected House of Lords Science and Technology Committee, Lords Porter and Flowers, to meet the new man. The possible appointment of a cabinet-rank minister to oversee science and technology will be raised.

At this stage, it is far from clear what the future holds for research spending. In the United States, for example, it was certain that last summer's budget crisis would be repeated in 1991 even before the economic indicators began to point unambiguously towards at least a mild recession, and at worst a full-fledged depression lasting for several years. That can only worsen the federal deficit.

So the outlook for the year ahead is not cheerful. Congress is clearly convinced that science is a critical part of the federal enterprise, and one that should have more money. Faced with layoffs in their home constituencies, however, congressmen's nerves will be tested severely if they are to keep their eyes on this distant prize. 